\title{
General Transcription Factor IIH Subunit 4
}

National Cancer Institute

\section{Source}

National Cancer Institute. General Transcription Factor IIH Subunit 4. NCI Thesaurus. Code C89760.

General transcription factor IIH subunit 4 (462 aa, $\sim 52 \mathrm{kDa}$ ) is encoded by the human GT F2H4 gene. This protein plays a role in both DNA repair and gene transcription. 